\title{
Corrigendum to "Simulation and Optimization of Lead-Based Perovskite Solar Cells with Cuprous Oxide as a P-type Inorganic Layer [J. Nig. Soc. Phys. Sci. 1 (2019) 72-81, https://doi.org/10.46481/jnsps.2019.13]"
} \author{
O. Muhammed ${ }^{\mathrm{c}}$ \\ ${ }^{a}$ Department of Physics, Nigerian Defence Academy, Kaduna, Nigeria \\ ${ }^{b}$ Department of Chemistry, Nigerian Defence Academy, Kaduna, Nigeria \\ ${ }^{c}$ Department of Physics, Bayero University, Kano, Nigeria \\ ${ }^{d}$ Department of Physical Sciences, Greenfield University, Kaduna, Nigeria
}

Eli Danladi ${ }^{\mathrm{a}, \mathrm{d}, *}$, M. Y. Onimisi ${ }^{\mathrm{a}}$, S. Garba ${ }^{\mathrm{b}}$, R. U. Ugbe ${ }^{\mathrm{a}}$, J. A. Owolabi ${ }^{\mathrm{a}}$, O. O. Ige ${ }^{\mathrm{a}}$, G. J. Ibeh ${ }^{\mathrm{a}}$, A.

DOI: $10.46481 /$ jnsps.2021.332

Article History :

Received: 06 August 2021

Accepted for publication: 13 August 2021

Published: 29 August 2021

(C)2021 Journal of the Nigerian Society of Physical Sciences. All rights reserved. Communicated by: B. J. Falaye

The original content of this published Article has an error in the name of one of the co-authors Eli Danladi which was written incorrectly as D. Eli. We highly regret this.

\footnotetext{
${ }^{*}$ Corresponding author tel. no: +2348063307256

Email address: danladielibako@gmail .com (Eli Danladi )
} 